\title{
amsterdamlawforum
}

\section{THE UNIVERSITIES: A NEW LEGAL GRAMMAR}

\author{
Grahame Lock*
}

\section{Introduction}

Every national European government has a higher education policy, even if some no longer have an education ministry within which such a policy is made. The British government, for instance, now assigns to a ministry called the Department for Business, Innovation and Skills the responsibility for the universities, presumably on the heavily ideological ground that university education has as its primary goal to produce students-with-a-diploma possessing the skills needed to enter business, as well as to make a contribution once there to what in most countries is disingenuously called the 'knowledge economy'.1

\section{Soft Law}

In all countries there are university laws, but in some they are, paradoxically, aimed at what is officially but misleadingly referred to as 'deregulating' the operation of the universities. Thus for instance in Germany "a ranking of state university laws was established, concerning their ability to provide universities with a deregulated legal framework, autonomy and ... competitiveness." 2 This 'deregulation' is rhetorically glossed as a set of 'newly achieved freedoms', making it possible for the institutions to transform themselves "from subordinate government bodies into competitively financed, independent institutions" 3 (ibid). Or, as we might otherwise put it, a fundamentalist neo-liberal ideology is to be imposed on the public universities, and any substantial democratic control is to be eliminated. Similarly in The Netherlands: "a policy has been conducted [there] since the mid-eighties which is based on great autonomy for institutions of higher education." Thus "the freedom of will of contracting parties ... is of great

\footnotetext{
* Faculty Fellow in Pbilosophy, Oxford University; Professor at Leiden University and Radboud University Nijmegen.

1 'This notion of the 'knowledge economy' is another reference now haunting debate on the function and future of the universities .... As opposed to what the spin suggests, the notion of the knowledge economy does not at root mean the restructuring of the economy on the basis of scientific knowledge. On the contrary, it means that knowledge production is to be 'economized': homo academicus is now to be modelled after homo economicus"; in G. Lock \& C. Lorenz, 'Revisiting the University Front', Studies in the Philosophy of Education, 2007, p. 411. 2 See http://ec.europa.eu/invest-in-research/pdf/download_en/final_report_v2_en.pdf (accessed on 2 May 2010).

${ }^{3}$ Ibid.
} 
importance", according to Roel van de Ven. ${ }^{4}$ As we shall see, this panEuropean move to 'deregulation' - one however accompanied in reality by audit-style hyper-bureaucratization - which is being channelled in particular by the Bologna Process, presents yet another example of the substitution of 'governance' for 'government", or of what has been called 'post-democracy'. We shall return to this theme.

What we shall discover, to anticipate, is not only a proliferation of governance mechanisms, but a parallel spread of 'soft law'. This term refers not to law which is not rigorously applied, but to the consequences of a blurring of the boundaries between on the one hand 'old-fashioned' parliamentary legislation and regulation, and on the other hand the 'political' imposition of norms which may but may not have any strictly legal foundation, and which have their source in complex stakeholder-driven processes. Thus Giuseppe Bronzini writes about "the instruments of 'soft law' and procedures such as benchmarking, peer review, best practices and mutual learning - originally adopted by corporation strategies and rewritten in a quasi-political context". ${ }^{5}$ In any case, in this manner the legal grammar of the administrative operation of the universities too has been fundamentally modified.

\section{The Bologna Declaration}

A leading example of this phenomenon is to be found in the Bologna Declaration of 1999, which created the so-called European Higher Education Area, introducing (among other things) procedures for applying 'quality assurance standards' (itself an audit-type approach to 'quality', borrowed from managerialist ideology and practice) and for standardizing academic degrees throughout Europe, though so far in incomplete fashion, by requiring the replacement of existing national diplomas by a more or less uniform Bachelor-Master model and the like.

One Dutch study of developments notes: "Higher education in Europe did not stand still in the past decade. On 19 June 1999, the ministers responsible for education of 29 countries in Europe signed the Bologna Declaration .... Building further upon the Sorbonne Declaration (1998), the Bologna Declaration emphasises the importance of the creation of a European Higher Education Area (EHEA) by 2010. One of the main pillars of the EHEA is the adoption of a system based on three main cycles: bachelor, master and doctorate. These three cycles were already established in Anglo-Saxon

4 'The European Union and Dutch higher education: law and policy' (1996), at http://www.cedefop.europa.eu/etv/Upload/Information resources/Bookshop/129/10 e n vandeven.pdf (accessed on 2 May 2010).

5 'Governance and the Development of Flex-Secure Labour Law', in The European Journal of Legal Studies, special number on Governance, Civil Society and Social Movements, June 2008 , p. 5. 
countries like the USA and the United Kingdom .... The Anglo-Saxon higher education systems inspired the ministers of education amongst others to make a start with the so-called Bologna Process. The harmonisation of the architecture of the European higher education systems had a large impact on universities. One of the signatory countries of the Bologna Declaration that first implemented the three-cycle system is the Netherlands. Already in 2002, the former higher education system of kandidaats-doctoraal was replaced by law with the bachelor-master system." Process is special because it is not organised by the (institutions of the) EU, but initially [was established] by the ministers of education of 29 countries. In 1999, the EU consisted of 15 member states .... In 2009, 46 countries are part of the Bologna Process and the EU consists of 27 member states. In this sense, Europeanisation is broader than EU-isation and stretches beyond policy making in the European Union."

\section{The Legal Status of the Bologna Process}

What then is the legal status of the Bologna Process, that has brought about the most far-reaching transformation for a very long time of higher education and more particularly of the universities?

Hauke Brunkhorst, professor at Flensburg University, argues that the national governments - and more especially the education ministries - made use of Bologna to play a familiar political game. In order to promote their own reform plans, they initiated the joint Bologna Process which, it was then suggested, required them to implement reforms of just this type. Thus, any criticism of the content of these invasive plans would have to be addressed not to them but to 'Europe' - for at the national level, it was suggested, little room for manoeuvre any longer existed. ${ }^{7}$

In other words, the Bologna Declaration of 1999 is an example of 'soft law'. De jure each European state is free to introduce the scheme or not, but de facto the process is imposed on all states. Thus Brunkhorst notes in particular that "the united executive powers of Europe and their 'privatepublic' partners [in this way] significantly extended their transnational class ascendancy, aggrandized their possibilities of action beyond any juridical limits and attributed to themselves previously undreamed-of prerogatives" (ibid).

6 S. den Bak, 'Europeanisation or Americanisation in Higher Education?', http://www.neth-er.eu (accessed on 2 May 2010). (The English has been silently corrected in the above quotes.)

7 G. Lock \& H. Martins, 'The European Universities, Citizenship and Its Limits: what won't solve the problems of our time', European Educational Research Journal, vol. 8, no. 2 2009; citing H. Brunkhorst, 'So wird Sachzwang gebaut', Die Tageszeitung, 12 August 2006. 
Why does the 'public-private' link play such a prominent place in this process? Especially because, as already noted, the Bologna Process is an instance par excellence of 'stakeholder governance' at a European level. Indeed, official documents on the project make use of this terminology: thus for instance, in a paper on the UK response to the Bologna process, we read that "Bologna Process stakeholders should continue to set tangible goals for the European Higher Education Area .... The Process should continue to be based on the strong involvement of key stakeholders .... Bologna Process stakeholders agree that there should be a renewed focus on explaining the Process reforms to all relevant parties. Particular attention should be paid to employers and to highlighting the employability of graduates from 'new' programmes" and so on. This, and much more, is governancespeak.

\section{Governance versus Government}

But what then distinguishes governance from government? In order to give a brief answer to this question, I shall draw on my own earlier analyses. ${ }^{8}$

Ian Scott has usefully summarized some central and paradoxical aspects of the (deliberately) blurry category of governance. ${ }^{9}$ The four pillars of post-democracy, on Scott's account, are (1) the 'disembedding' of political elites; (2) the trivialization of politics; (3) rule via the 'cadastral map'; and (4) the breakdown of institutional 'pillarization'. By the disembedding of political elites, Scott means the tendential freeing of those elites from control by the mass of citizens, who come to play ... a "passive, quiescent, even apathetic part", as well as an ever tighter control by the political class over the citizens, via a strengthening of State security and secrecy. The trivialization of politics involves a "subordination of politics to organization" as well as a "reduction of the science of politics to the science of administration". Thus politics is reduced to 'management', with a consequent marginalization of the power of parliaments and even of executives, accompanied by an increased 'personalization' of whatever remains of political life. 'Public opinion' becomes a key domain of measurement but also of manipulation; and such manipulation by the mass media (the politics of 'image' and 'spin') becomes a crucial instrument in this connexion. Rule via the 'cadastral map' involves a system of "rituals of verification", especially via dogmas of target-setting (organizational 'goals', 'mission statements' and the like) as well as procedures of evaluation, auditing, accreditation and so on (all of which, in spite of appearances and Public Relations claims, are essentially artificial, at a great bureaucratic distance from reality). Thus all public bodies, and even political parties and

8 In 'Watching out for "governance": the nature and future of an illusion', Episteme: Revista de Epistemologia e Historia das Ciencias, Lisbon, nos. 15-16-17, 2005-6.

9 Scott, at http://wuv.uibk.ac.at/pdf/Governance.pdf (accessed on 2 May 2010). 
governments, come to adopt the terminology and methods of managerialism, which are derived from the business sector. This point can easily be verified by listening to or reading almost any statement by a government minister or political leader of our day: their langue de bois - that is, their choice and mix of clichés - will immediately reveal their language to have been infected by the managerialist virus. Finally, the breakdown of institutional 'pillarization' signifies the "increasing homogenization of styles of institutional governance", as well as an ever-growing permeability of the line between State (public sphere) and market (private sphere), which means in effect an opening of the State to corporate interests, itself resulting in growing corruption within the public sector. This public sector generally (health, education, public services) is restructured on the 'business model', leading on the way to a loss of public service spirit. Meanwhile, political party programmes 'converge', leading to a 'vapid' politics (idem).

In these circumstances, political decision-making with citizen input is tendentially replaced by governance processes with often decisive 'stakeholder' input, in which the more powerful stakeholders - typically, large business enterprises and the like - have a more powerful and even privileged position.

\section{The Legal Grammar of Education}

What consequences does all have for the politics of education and for its legal grammar? The reforms in the mode of regulation cannot be understood in purely technical terms but are linked to substantive political goals. Thus, as I have argued in various publications, the ultimate aim seems to be to transform the whole of higher education - in fact, education as a whole, including the schools - into an instrument serving the quantifiable economy, in the banal capitalist sense. This implies, in the policy language to which we have become accustomed, the 'marketization' of teaching and of research; ${ }^{10}$ or perhaps better, the subjection of education to a religion of the market, with its own God, efficiency, ${ }^{11}$ and its high priests, the ever expanding caste of New Public Managers. The task of these inquisitors of the market religion includes the imposition of marketspeak (the forcible replacement of one vocabulary by another is in itself a considerable instrument of power) as well as of the rituals of 'rationalization', 'evaluation', 'accreditation', 'audit' and the like - of which we shall briefly say more below and which are, in their hyperbureaucratic institutional embodiment, the ineluctable pendant of the 'turn to the market'.

10 See Hermínio Martins, 'The marketisation of universities and some cultural contradictions of academic capitalism', in Metacrítica, Revista de filosofia, Lisbon, no. 4, 2004. 11 See Pierre Legendre, Le désir politique de Dieu, Paris: Fayard, 1988, p. $63 \mathrm{ff.}$ 
This, it may be argued, is the underlying logic of practically all education policy today. The practical details in any given land or institution are of course more complicated: there is confusion, resistance, struggle and, on the side of governments, massive incompetence in attempts to impose this logic. But prodigious financial resources are being invested by governments in the reform project, which is now also backed up at a European-wide level by the above-mentioned Bologna Agreement.

\section{Vagueness and Confusion}

So these substantive goals and the new regulatory regime are linked. This has led to some considerable confusion at the level of university administration. Nor is this confusion new: it applies generally to the relation between Europe or the European Union and the nation States in the domain of education (as in other domains). Van de Ven already wrote: "The direction of educational co-operation has not become any more predictable for the Member States since 'Maastricht', and judicial 'surprises' remain possible .... The norms in the action programmes, for example, are intentionally kept vague .... The discussion on powers is characterised by ambiguity .... The legal framework with regard to European co-operation in education is complex and it is - in my view too readily - assumed that European policy cannot have any legally binding consequences." But the author points out that "the position in the case of non-specific legal acts is generally such that norms often arise which do not have any legal force in the formal sense .... That which cannot be attained by regulation is partly accomplished using contracts / public-law agreements between the Commission and educational institutions. It is remarkable that this form of influencing of national education receives virtually no political and scientific attention, despite the fact that the consequences for national education may be huge." This is roughly what we meant by the 'governance way' of policy-making and its substitution for straightforward legislative provision. And the situation has become only more confusing since the Bologna process began to operate.

\section{A New Political Grammar: Surveillance and Audit}

Chris Lorenz argues that "the political context of the Bologna Declaration and its accompanying declarations consists of neo-liberalism and of neoliberal public policy - so-called New Public Management (NPM)". This means that the new legal grammar of higher education in Europe is paralleled by a new 'political grammar', which determines what political moves - what policy options - are available within the reformed and still reforming system. In short, and simplifying, we can say that the only policy options now considered by western European governments are those which fit into this straitjacket of the so-called 'modernization' of the public sector - that is, its transformation into a hyper-audited instrument for the satisfaction of the demands of the middle and upper sectors of the labour market, or, to use the other platitude constantly repeated in policy documents, of the needs of the 
'knowledge economy' (see above). The hyper-auditing - endless and ever more expensive rounds of visitation, evaluation, accreditation and the like becomes necessary when control of the universities is taken out of the hands of the professionals, that is, the academics themselves, and seized by a management stratum acting as proxy for external (political and business) interests. Since many or most academics do not share this ideology of the universities' raison d'être, they cannot be trusted to bend their institutions in the newly demanded direction. Thus ever more invasive surveillance and control by the New Public Managers is required, which is translated into the (fake) audit mechanisms already referred to. That these are fake mechanisms is convincingly argued by Bruce Charlton and Peter Andras. ${ }^{12}$ The mechanisms are publicly claimed to measure the 'quality' of university teaching and research and, ever more often, to determine whether the level of such quality merits the title of 'excellence' - itself the most over-used and emptiest predicate in the sphere of education. ${ }^{13}$ Central to educational audit is thus 'quality assurance'. But

[Quality Assurance] implicitly chose the criterion of pure, abstract 'auditability' as its benchmark. 'High quality' teaching was defined as that which was comprehensively and selfconsistently documented in a closed system. This meant that [the Quality Assurance] definition of high quality teaching was an ... explicit system characterised by Mission Statements, aims and objectives, flowcharts, monitoring, feedback and formal procedures for all imaginable contingencies.

By itself, this definition of quality is neutral in evaluative terms - however the public relations 'spin' of [Quality Assurance] equated this technical definition of teaching quality with the general language usage of 'high quality' which has to do with excellent outcome measures, not system properties. ${ }^{14}$

In other words, the 'quality audit' procedures now dominating university policy in all western European states, and 'legitimated' by the Bologna Process, have nothing to do with real-life quality, but are rather an incestuous tool for determining only whether any politically or administratively imposed 'goal' - often polished for Public Relations purposes into (see above) a 'mission statement' - is or is not attained by a given institution: rather like the Soviet Five-Year Plans, which notoriously delivered (or over-delivered)

12 Auditing as a tool of public policy - The misuse of quality assurance techniques in the UK university expansion', at http://www.staff.ncl.ac.uk/peter.andras/CAEPS.pdf (accessed on 2 May 2010).

13 See Bill Readings, The University in Ruins, Cambridge, Mass.: Harvard University Press, 1996, p. 24, as summarized: "Excellence is a de-referentialised term, having no category of its own. Its lack of reference and content allows it to function as a principle by which very different categories - teaching, services, research - can all be termed excellent and thus lacks meaning: "The appeal of excellence marks the fact that there is no longer any idea of the University, or rather that the idea has now lost all content."'

14 Lorenz \& Andras, idem. 
everything that higher authority demanded, according to the 'quality' and 'quantity' criteria of the State, while however conspicuously failing to deliver much of what the people in fact needed.

\section{Conclusion}

There is no space here to look deeper into this strange phenomenon of the split between administrative logic on the one hand and real (academic) life on the other. ${ }^{15}$ The point argued in this piece is that the legal as well as the political logic of present-day higher education and especially university policy are such as almost entirely to mask the rationality of real-life academic life and needs. The educational policy sphere is now a bubble, far removed from reality, and accelerating towards a disaster waiting to happen.

That does not mean that there are not many teachers and researchers, and even administrators, at all levels, who are desperately trying, in the face of this legal (or, as in the case of the Bologna Process, quasi-legal) and political tsunami, to find some academic shelter, to protect their institutions from the worst excesses of these developments or at least to find or construct niches within which academic work can continue. But individuals are, in the longer run, largely powerless against the nefarious legal and political grammar to which the universities are now being forced, by compelling juridical and administrative instruments - including the soft legal logic of neo-capitalism to submit.

- The Amsterdam Law Forum is an open access initiative supported by the VU University Library -

15 See on this point Burkard Sievers, 'The Psychotic University', at http://www.ephemeraweb.org/journal/8-3/8-3sievers.pdf (accessed on 2 May 2010). 